\title{
Political Communication Strategy in Legislative Elections: A Case Study of Nasrul in the Period of 2019-2024 in Payakumbuh City
}

Muhammad Danil ${ }^{1}$, and Erliza Fitri ${ }^{2}$

${ }^{1}$ Sekolah Tinggi Agama Islam Negeri Mandailing Natal, Panyabungan Kota, Indonesia

${ }^{2}$ Universitas Islam Negeri Imam Bonjol, Padang, Indonesia

\begin{abstract}
This study discusses the political communication carried out by Nasrul in the 2019-2024 legislative elections in Payakumbuh City. The focus of this research is on the elected candidates from the Prosperous Justice Party (PKS) due to being elected as a member of the DPRD Payakumbuh City with the most votes. The author assumes that his victory was motivated by good political communication. This research is a field research with a qualitative approach, while data collection is carried out through interviews with direct respondents Nasrul as the main source and secondary sources are the head of the PKS faction, a team of volunteers, community leaders who were selected based on sampling. The purpose of this study was to "know about the political communication used by Nasrul in the legislative elections" in Payakumbuh City for the 2019-2024 period. The results of this study, get the following conclusions: first, the political communication strategy used by Nasrul: 1) Nasrul uses the style of public relations communication (building relationships with the community). 2) Delivering political messages in the form of vision and mission. 3) Using media outside the campaign space such as stickers and calendars. 4) The effectiveness of Nasrul's political communication that is getting support in the form of voting in the legislative elections with acquiring 986 votes in electoral districts III (East Payakumbuh and North Payakumbuh).
\end{abstract}

Keywords: strategy; communication; politic, election, legislative

\section{Strategi Komunikasi Politik Pada Pemilu Legislatif: Studi Kasus Nasrul Pada Periode 2019-2024 Di Kota Payakumbuh}

\begin{abstract}
ABSTRAK
Penelitian ini membahas tentang komunikasi politik yang dilakukan Nasrul dalam pemilu legislatif periode 2019-2024 di Kota Payakumbuh. Fokus penelitian ini terhadap caleg terpilih dari Partai Keadilan Sejahtera (PKS) disebabkan karena terpilih menjadi anggota DPRD Kota Payakumbuh dengan suara terbanyak. Penulis berasumsi bahwa kemenangannya dilatarbelakangi adanya komunikasi politik yang baik. Penelitian ini adalah penelitian lapangan (field research) dengan pendekatan kualitatif, sedangkan pengumpulan data dilakukan melalui wawancara dengan responden Nasrul langsung sebagai sumber utama dan sumber sekunder adalah ketua fraksi PKS, tim relawan, tokoh masyarakat yang dipilih berdasarkan pengambilan sampel. Tujuan penelitian ini untuk mengetahui tentang komunikasi politik yang digunakan oleh Nasrul dalam pemilu legislatif di Kota Payakumbuh periode 2019-2024. Hasil penelitian ini, mendapatkan kesimpulkan: pertama, Strategi komunikasi politik yang digunakan Nasrul: 1) Nasrul menggunakan gaya komunikasi public relations (membangun hubungan dengan masyarakat). 2) Menyampaikan pesan-pesan politik berupa visi dan misi. 3) Menggunakan media luar ruang kampanye seperti stiker dan kalender. 4) Efektifitas dari komunikasi politik Nasrul yaitu mendapat dukungan berupa pemberian suara pada pemilu legislatif dengan perolehan 986 suara di dapil III (Payakumbuh Timur dan Payakumbuh Utara).
\end{abstract}


Kata kunci: strategi; komunikasi; politik; pemilu; legislatif

\section{INTRODUCTION}

Law No. 7 of 2017, concerning "Organization of Elections states that the institutions authorized to conduct elections are the General Election Commission (KPU), Election Supervisory Body (BAWASLU), and the Election Organizing Honorary Council (DKPP). As a unitary function of organizing elections, to elect members of the Regional People's Representative Council, the President and Vice President, and to elect members of the Regional People's Legislative Assembly directly by the people. And furthermore, Law No. 7 of 2017 also contains provisions regarding the holding of simultaneous elections, namely the elections for the DPR, DPD, DPRD and the Presidential Election which will be held for the first time in 2019.

Elections as a legislative election event aim as a method for selecting leaders. Alternative public policy (Public Policy) is to strengthen a democratic state administration system, realize elections that are fair and with integrity, ensure consistency in the regulation of the electoral system. Elections are the transfer of conflicts of interest from the community to the House of Representatives (DPR), so that the elected representatives can maintain guaranteed community integration, strengthen the democratic state administration system, realize fair elections and with integrity. Then the goal is as a means of mobilizing, mobilizing people's support for the State and government by participating in politics (Prihatmoko, 2003).

Every political communication always includes political messages, political communicators, media or political channels, who is the communicant, and what kind of effect. This results in an effective political communication process. When political communication takes place, what is influential is not only the political message, but who is the political figure/actor who conveys the political message. In other words, the credibility of a political communicator and political institutions (parties) that support it will determine the success or failure of political communication (Ardial, 2009). Although figures and parties are the key to success in political communication, the public is more focused on the personality of the candidate candidate, not the ideology of the party. So that prospective candidates are asked to convey their vision and mission. "Nankyung Choi in his book Local Politics in Indonesia Pathways to Power", that the victory of a candidate candidate is not determined by the party, but rather by the candidate's figure (Choi, 2011).

If the communication is able to change a person's attitudes and actions, it can be said that the communication has been successful (Susanto, 2017). In terms of politics, communication is a process that involves talking. But not talk in a narrow sense, but talk in a broad sense such as all the ways people exchange symbols, written and spoken words, pictures, movements, gestures, temperament and clothes (Arifin, 2011).

The results of political party votes in the legislative elections in Payakumbuh City in the 2019- 
2024 period, the Prosperous Justice Party (PKS) became the focus of the author's research, because he was successfully elected as a member of the People's Representative Council (DPRD) for the second time in Payakumbuh City. The author assumes that his victory was motivated by good political communication. He is Nasrul (PKS). With Nasrul's 986 votes. This is the reason the research will focus on this selected candidate, namely Nasrul. Even though the party carrying the candidates received a low number of votes, in terms of their political personality, they were able to gain the trust of the voting public to become the people's representatives in the government.

Voters are assumed to have different motives in determining their choice. The performance of the candidates, the vision and mission of the work program and even financial benefits often motivate voters to channel their votes. Therefore, the political communication strategy of the candidates becomes an important part in winning voters' votes. During elections, political parties nominate their cadres to be elected by the people with the aim of becoming people's representatives in the government. Party cadres (legislative candidates) appear in the midst of society by presenting their Ideology, Vision and Mission which aims to connect political thoughts, and build relationships between legislative candidates and their elections. Therefore, they must have good communication with the voting community, because without effective communication, political activity will lose its form (Maran, 2007).

Based on the description of the thoughts above, the authors are interested in finding answers to the question "what kind of communication strategy was implemented by Nasrul in winning the Payakumbuh City election for the 2019-2024 period?" This study aims to determine the form of communication and the effects of the 2019-2024 Payakumbuh legislative election on Nasrul's voice. Meanwhile, the benefit of this research is to make a new contribution to the development of political science, especially political communication and its strategy.

\section{METHODS}

The research method is basically a scientific way to get data with certain goals and uses (Sugiyono, 2014). This research is a field research that provides a complete picture of a situation at the research location without the intention of comparing or comparing. The data taken from this study are primary data taken directly from Payakumbuh DPRD members, namely Nasrul and secondary data obtained from volunteers, community leaders, political figures, General Election Commission (KPU) Payakumbuh. Meanwhile, related to data collection techniques, the writer did it through direct interviews with Mr. Nasrul, the sikses team, the KPU, community leaders and the general public. The selected informants are informants who are directly involved in this election.

Data obtained from interviews, observations are strengthened through documents owned by the successful TEAM related to the program of activities for winning candidates, as well as photos of the involvement of candidates in the activities held. From the interview point of view, the question is related to the strategies implemented by legislative candidates; starting from the approach, communication model, to implementing the approach to the community. While the time of data collection was in September-December 2019. The data obtained were processed 
as well as possible through overall reading which was then coded, and data reduction was carried out continuously during the study, then interpreted the meaning of the display of empirical material, while the final data obtained through testing the new validity and reliability ends with drawing conclusions.

\section{RESULT AND DISCUSSION}

The method of political communication is the scope of the political strategy of politicians, so that the method that the author intends in this paper is included in the category of strategy. Where the method is an orderly and systematic way of working to be able to carry out an activity easily in order to achieve the specified purpose (Meity Taqdir Qodratillah, 2008). While strategy is the science of techniques or tactics, ways or tips to achieve something desired (Tim Prima Pena, 2006).

According to Arnold Steinberg in Toni Pito Andrianus' book, strategy is a plan for action, the preparation and implementation of a strategy affects the success or failure of a strategy in the end, so strategy is a plan for action. While the preparation and implementation of strategies affect the success or failure of the strategy (Pito, 2006). Sun Tzu explained regarding strategy that, in choosing a strategy, there must be a priority. Furthermore, he argues that the best form of leading a war is to attack the opponent's strategy, the second is to destroy the opponent's alliance (Varma SP, 2010). According to Peter Schroder, to be able to attack the opponent, the opponent's strategy must be identified first, therefore the recognition of the opposing party is very important. Otherwise, political actors will not recognize the opponent. Attacking the opponent's strategy means interfering with the implementation of the opponent's strategy, so that the opponent cannot realize it. If information regarding the opponent's strategy is not obtained, then the opposing alliance must be destroyed or at least disrupted. This can be done either through attractive offers or by undermining the credibility of the opponent or undermining the alliance's trust in the opponent (Schroder, 2018). Toni Andrianus Pito in his book mentions four political strategies, namely: reinforcement strategy, rationalization strategy, inducement strategy, confrontation strategy (Pito, 2006).

Communication is the process of delivering a message by one person to another to inform or change attitudes, opinions, and behavior, either directly or indirectly. The term communication or in English "communication" comes from the Latin "cimmunicatio", and comes from the word "communis" which means the same (Nur, 2019). Sama is meant here is the same meaning, with the intention of changing thoughts, attitudes, and behavior, then the recipient does what the communicator wants. Communication is not just information from a source to the public, it is more easily understood as the re-creation of information ideas by the public if given instructions with symbols, slogans, or main themes (Nimmo, 1993).

Communication and politics have a close and special relationship, because they are in the political domain by placing communication in a very fundamental position. Political communication can connect all parts of the political system, so that aspirations and interests have turned into a policy. Communications that talk about political studies are sometimes claimed to be studies related to the political aspects of public communication, and are also often referred to as campaign communications because they cover issues of persuasion 
(persuade) against voters, debate between candidates, and the use of mass media as a campaign tool. Hafied Cangara, 2009).

When political communication takes place, what is influential is not only the political message, but who is the political figure/actor (personality) or activist figure from which institution will convey the political message. In other words, the credibility of a political communicator (prospective candidate) and political institutions (party) that supports it will determine the success or failure of political communication in achieving its goals and objectives (Ardial, 2009).

There are several elements contained in political communication, namely political communicators, political messages, the media used, and the effects of political communication. Nasrul applies in his political communication, there is a process that systematically carries out clear elements such as communicators, messages, media channels, and the impact of political communicators. Delivering political messages by making public speeches will develop public interviews and lead to a clear persuasion process. Nasrul is the main communicator in conveying his message or political information. Direct dialogue, the art of speaking is one of the characteristics and is the main capital in influencing the community. So that political messages (persuasive) can be conveyed properly. According to a resident of Koto Panjang Payobasung named Kasmawati said "we as a community here are happy with Mr. Nasrul, he is polite and his speaking style is easy to understand". (Kasmawati, 2019)

This face-to-face communication method is practiced by all political candidates, including Nasrul, because this method can be a direct link between candidates and the public as potential voters. While the information related to the method applied by Nasrul the author got through several directly related sources, namely;

Table 1 List of Informants

\begin{tabular}{|l|l|l|}
\hline No & Nama & Jabatan \\
\hline 1 & Nasrul & Anggota DPRD \\
\hline 2 & Akhrijal & Tim Sukses \\
\hline 3 & Burhani & Masyarakat \\
\hline 4 & Dasril & Masyarakat \\
\hline 5 & Yosi Henisera & Masyarakat \\
\hline 6 & Yusmaini & Masyarakat \\
\hline 7 & Mursal Hedi & Ketua KPU Kota Payakumbuh \\
\hline
\end{tabular}

Source: Researchers notes

Some of Nasrul's political communication methods in the legislative election campaign for members of the Payakumbuh City DPRD for the 2019-2024 period.

1. The method of direct dialogue with the community

Nasrul's interpersonal communication is more directed at building relationships with the community. Nasrul building relationships with the community is something that is very valuable for himself and the community. Because this relationship will have a positive impact, especially for the community and Nasrul, the relationship is built not only through formal forums but also carried out outside of it such as dialogue in stalls, roads and so on. This dialogue 
does not only focus on community complaints such as irrigation and sewer problems, but also discusses employment opportunities for teenagers who do not continue their higher education. The meeting held by Nasrul during the campaign was arranged by the success team that had been formed, he said "that the success team is not allowed to convey persuasive messages (persuade) to residents directly or indirectly" (Nasrul, 2019).

Getting closer to the community is one form of communication link between candidates and citizens. The activities carried out by almost all legislative candidates are to convey the vision and mission of the campaign. Nasrul also carried out activities that took the form of this approach. Moreover, this activity was carried out outside and around the villages of East Payakumbuh and North Payakumbuh, such as holding meetings and direct dialogue with the people of Padang Alai Bodi and Koto Panjang Payobasung.

The purpose of this activity was to discuss the improvement of facilities and infrastructure in the Koto Panjang Payobasung and Padang Alai Bodi areas (January, 2019). Previously, Nasrul also invited several residents from Koto Panjang Payobasung to have direct dialogue in order to accommodate the aspirations of the community in early February 2019 (Yentri, 2019). this will be done well, as conveyed by Yentri. We also hold community meetings. Such as the community meeting of the Padang Alai Bodi and Koto Panjang Payobasung villages, and the success team asked for permission from local community leaders to hold a meeting with the local community to hold a meeting with the community that in order to be nominated as a member of the Regional Legislative Council of Payakumbuh City, Nasrul will socialize his vision and mission in the district III ( Koto Panjang and Body) (Yentri, 2019). The results of Nasrul's political communication gave birth to its own views for the community as stated by Mrs. Nelvi who said that "Mr. Nasrul is a person who is not favoritism and does not discriminate against the people. people close to Mr. Nasrul. I saw Mr. Nasrul come to pay homage in the Koto Panjang Payobasung and Padang Alai Bodi areas” (Nelvi, 2019).

In addition, Nasrul also accommodates the aspirations of local residents to be discussed at the Payakumbuh City DPRD. Although during the campaign campaign at that time, in an open dialogue, Nasrul did not say that he would run for the second time as a member of the Payakumbuh DPRD, he also said that "showing performance as a member of the DPRD who cares about the people will make the public think that he is campaigning, so there is no need to tell directly" (Nasrul, 2019).

Nasrul's political communication activities were then actively involved in mutual cooperation. One of them built an access road from Padang Alai Bodi to Jalan Koto Panjang Payobasung in 2017. Then there were also some fellow DPRD members who contributed (Nasrul, 2019). Although seeking financial assistance for infrastructure development has become his duty. On one occasion Nasrul explained: "I did this mutual cooperation because I wanted to mingle with the residents, as well as to build a sense of concern for regional development. Mingling with the people, for me, is the same as building a commitment without distance. So, I can accommodate the aspirations of the people, and vice versa, and I certainly do all of that for the sake of the progress of the East Payakumbuh and North Payakumbuh regions" (Nasrul, 2019). 
With a hoe and the help of mutual cooperation, it was carried out, as explained by Dody, one of the residents. "We as residents are very happy. Through gotong royong activities held by Datuk Giman at that time, residents could help in the process of making irrigation to the community's rice fields. Rarely do officials want to step down and care about the community" (Dody, 2019).

By holding a mutual cooperation event held by Nasrul, it indicates that placing a sense of togetherness is very important in establishing good communication with the community. Because if an official is able to place himself in the midst of society, it will cause sympathy from the community. The author understands that in the application of political communication, Nasrul uses the following methods.

\section{Understanding the Audience (society)}

a. Creating an atmosphere of greatness and harmony with the community.

b. Shows a sense of concern for orphans.

One of the communication strategies carried out by Nasrul is through the millennial generation. As a generation of PKS, he mostly does blusukan through activities in the community.

\section{Visiting Relatives}

At the end of December 2018 he visited his relatives who live in the village of Padang Alai Bodi, East Payakumbuh sub-district to other neighbors. This activity is done to ask for blessings. This is an important first step for someone who will nominate as a representative of the people, because relatives also play an important role in promoting the vision and mission of the campaign. Yusmaini when interviewed by the author stated, "Pak Nasrul not only does things like other people do, such as campaigning before the election, but before the campaign Pak Nasrul has visited his closest relatives with the intention of asking for their blessing and socializing his vision and mission, and we As a society, we consider that Mr. Nasrul can indeed be an accomplice of the community in the future, because during the 2014-2019 period, our aspirations, thank God, have always been realized" (Yusmaini, 2019).

\section{Attending Youth and Yasinan Wirid}

In this case, Nasrul made various visits to various religious communities, either by initiative or by invitation. One of them is attending youth wirid at the Bonai and Koto Panjang mosques in Payobasung in East Payakumbuh and North Payakumbuh. Not only visiting, even Nasrul as a speaker at the event. During his visits to various religious events, one of which was the youth wirid event, Nasrul never openly campaigned, only introduced himself and became a speaker at the event. Then the organizers of the event conveyed to the public that Nasrul would run again as a member of the Payakumbuh City DPRD. As stated by Nasrul's success team, Anton said:

"When attending a religious ceremony, one of which was the youth wirid activity, the wirid event administrator conveyed to the public that Mr. Nasrul who came to visit the event was a candidate who was running for the Payakumbuh DPRD level. So that we as a successful team do not need to convey it directly. So we are not considered to be campaigning in mosques, because campaigning in mosques is prohibited, but we are good at approaching our constituent communities, sometimes the places we go to understand by themselves" (Anton, 2019). Then attending wirid yasin which is held twice a month is one of the places for routine activities 
involving Nasrul. When the community carried out wirid yasin, Nasrul was present at the wirid yasin event, and participated in carrying out wirid yasin which is a routine event in East Payakumbuh and North Payakumbuh. What Nasrul did was the application of political communication used in accordance with political campaign theory.

\section{Vision and Mission as Nasrul's Political Message}

Political messages usually contain ideas that indirectly affect the public or voting community. Nasrul said that "there are no special messages, only to provide an understanding to the public that in choosing a legislative candidate, one must know who that person is and explore their nature, then also convey our vision and mission" (Nasrul, 2019). The vision and mission conveyed by Nasrul in the dialogue with the residents are:

Vision: "Creating an easy generation that is tough, independent, skilled and has noble character".

Mission:

A. Conducting youth activities in the community.

B. Conducting trainings in agricultural business, commerce and creative business.

C. Assisting in community service and protecting the environment.

D. Improving achievement both in sports and other scientific fields.

E. To strengthen the ties of brotherhood with regular meetings.

According to one resident of the Koto Panjang Payobasung village, Marlinda, stated that, "When Nasrul appeared in front of the public during the 2019 election campaign, he only spoke about the vision and mission" (Marlinda, 2019). Although Nasrul did not convey specific political messages or appeals to the community, he repeatedly conveyed his vision and mission when addressing the public using beautiful spoken language (rhythms, expressions, and voice intonation) forgetting one of the effective ways to hurt people in their actions. give support.

\section{Party Stickers, Calendars and Posters As Political Media}

In addition to conducting visits to a number of community elements in order to socialize the vision and mission, Nasrul also conducted a number of information dissemination through political media. Political media channels are tools or means commonly used by communicators in conveying their political messages. For example, such as print media, such as newspapers, tabloids, magazines. Then electronic media, such as radio, television, computers. Furthermore, small format media, such as pamphlets, brochures, leaflets, and stickers. Then outdoor media, such as billboards, banners, billboards, flags, tassels, pins, logos, hats, vests, T-shirts, calendars, note blocks and everything that can be used to build the image of "image building" (Hafied Cangara, 2009). Legislative candidates must be selective in compiling messages from a communication that they want to launch, in the sense of adjusting to the circumstances and conditions of the audience, so by themselves in terms of using the media it must also be the same.

In this context, Nasrul launches messages in his political media using persuasive language in the sense of inviting or persuading. As for the message, it is like the image of the nation, let's use our voting rights, don't forget April 17, 2019. This message was used in party posters with the intention of inviting the public to exercise their voting rights. Printed posters as many as 50 sheets. Then Nasrul also used calendar media, and in the calendar was also inserted a message, 
namely "to create a strong da'wah party in service to the people, nation and state", the use of short messages in political media aims to invite or appeal to constituents to exercise their right to vote. by selecting the sender of the message.

The media channels used by Nasrul are using outdoor media, such as calendars, party posters, stickers. There were 50 calendars made by Nasrul and the calendars were also distributed to the people of North Payakumbuh and East Payakumbuh as well as to relatives, and relatives in the DPRD Office when they were members of the council in the previous period. This outdoor media contains messages or appeals addressed to all circles of society, youth groups or organizations. According to Nasrul, political targets must include all levels of society, with the aim that all political messages are conveyed as a whole. As Nasrul said in the interview:

"Political targets must cover all aspects, be it the lower middle class or the upper middle class, approaches with young people, with friends, and co-workers. I take these approaches so that my political ideas can be accepted as a whole" (Nasrul, 2016).

Formulating messages in Nasrul's media did not involve members of his success team, the success team was only involved in spreading the media. The distribution of media such as calendars, stickers and posters he gave as gifts to the community after holding a gathering with relatives and meeting residents (Nasrul, 2019). As for the form of political media used by Nasrul, 50 stickers measuring 9x5 cm contain a message that urges voters to ask for support. In addition, it contains a political message which is interpreted as an invitation to choose one's party. The sticker distribution process was carried out by the success team, relatives, and a number of residents who supported it.

Then the distribution of calendars to the public is one way for Nasrul to convey political messages through the media. The calendar contains photos of Nasrul's documentation of his various social activities. Things like this indirectly inform the public that Nasrul is a populist figure. The distribution process is in line with the distribution of stickers, which are assisted by the success team and the people closest to them.

Nasrul did not put up advertisements such as posters along the road, especially in the eastern part of Payakumbuh City and North Payakumbuh City because there were no funds and political will, but because of the encouragement and support from the people of East Payakumbuh and North Payakumbuh, Nasrul ran for office. second time becoming a member of the Regional People's Representative Council (DPRD) as a complement to the III electoral district (Nasrul, 2020).

\section{Nasrul Political Communication Effects}

The various communication methods used by Nasrul are illustrated through his political communication activities. Nasrul's political communication activities were carried out during the campaign. Political campaigning is a process of introducing oneself as it is to the public, so that the public knows what kind of representative the candidate is so that it will have a positive impact on the candidate.

Nasrul's method of political communication has had a positive effect on him. This is evidenced that he got the most votes in electoral districts III (East Payakumbuh, North Payakumbuh) in 
the 2019-2024 legislative elections. Not only did he receive positive effects, he also received negative influences from his political opponents as stated by Nasrul "I I have invested a lot of political investment in the community, so that I get a positive response in the eyes of the community, I also feel the negative effects, and that too, in my opinion, comes from political opponents" (Nasrul, 2019). The methods of Nasrul's political communication are:

1. Strengthening the Character (personality)

a. Trying to commit to the community in building roads and making irrigation in Koto Panjang Payobasung Village in a better direction.

b. Trying to build public trust in a transparent and more consistent way in managing roads and making irrigation in the Koto Panjang Payobasung sub-district.

\section{Strengthening Institutions}

a. Conducting gatherings in order to build emotional relationships, such as attending mutual cooperation activities, cleaning irrigation facilities with residents in Koto Panjang Payobasung and Padang Alai Bodi.

b. Conducting political speeches in front of the community as a way of influencing the audience, one of which is direct dialogue with the people of Koto Panjang Payobasung and Padang Alai Bodi villages in order to accommodate the aspirations of the people in January 2018.

\section{Compose a Persuasive Message}

a. Trying to repair roads in the villages of Koto Panjang, Payobasung and Padang Alai Bodi in a better direction.

b. Trying to make irrigation to irrigate rice fields.

c. Strive to improve existing facilities and infrastructure.

d. Trying to find work places for people who have graduated from high school in Koto Panjang Payobasung and Padang Alai Bodi.

e. Strive to participate in creating a prosperous society.

\section{Media Used}

Using outdoor media such as billboards, stickers, calendars. From the results of the study, it can be seen that Nasrul had planned a method of political communication before the election took place. This can be seen from the formation of media campaigns, and communication models. Meanwhile, to overcome communication barriers is done with the efficiency of funds. In addition, Nasrul also evaluates, meaning whether his political communication has an effect on society.

Nasrul's vision and mission as a candidate for the Partai Keadilan Sejahtera (PKS) is to create a missionary party that is strong in service to the people, nation and state, which means that he will serve the progress of the region and the welfare of society if Nasrul sits in the seat of government later. Nasrul realized that being elected and trusted by the people of the electoral district for the three electoral districts was to represent the people's voice for the welfare of the community.

In Nasrul's form of political communication, there is a process that systematically carries out clear elements such as communicators, messages, media channels, and the effects of political 
communication. Nasrul appears as a communicator trying to convey political messages, namely programs that have been proposed to the public by making public speeches that will develop public discourse and carry out a clear persuasion process.

In implementing his political communication, Nasrul has used a public relations style of communication, namely. Political rhetoric is an art of speaking that has a very high political persuasion power, using beautiful spoken language (rhythm, expression, and voice intonation). Then Nasrul used outdoor media such as banners, stickers, posters, calendars that contained an identity and an appeal to vote for them.

\section{CONCLUSION}

This study discusses the political communication carried out by Nasrul in the 2019-2024 legislative elections in Payakumbuh City. The focus of this research is on the elected candidates from the Prosperous Justice Party (PKS) due to being elected as a member of the DPRD Payakumbuh City with the most votes. The author assumes that his victory was motivated by good political communication. This research is a field research with a qualitative approach, while data collection is carried out through interviews with direct respondents Nasrul as the main source and secondary sources are the head of the PKS faction, a team of volunteers, community leaders who were selected based on sampling. The purpose of this study was to "know about the political communication used by Nasrul in the legislative elections" in Payakumbuh City for the 2019-2024 period. The results of this study, get the following conclusions: first, the political communication strategy used by Nasrul: 1) Nasrul uses the style of public relations communication (building relationships with the community). 2) Delivering political messages in the form of vision and mission. 3) Using media outside the campaign space such as stickers and calendars. 4) The effectiveness of Nasrul's political communication that is getting support in the form of voting in the legislative elections with acquiring 986 votes in electoral districts III (East Payakumbuh and North Payakumbuh).

\section{REFERENCES}

Ardial. (2009). Komunikasi Politik. PT Indeks Permata Puri.

Arifin, A. (2011). Komunikasi Politik. Graha Ilmu.

Hafied Cangara. (2009). Komunikasi Politik (Vol. 4, Issue 1, pp. 163-180).

Maran, R. R. (2007). Pengantar Sosiologi Politik. Rineka Cipta.

Nankyung Choi. (2011). Local Politics in Indonesia: Pathways to Power. Routledge.

Nimmo. (1993). Komunikasi Politik: Komunikator, Pesan dan Media. Remaja Rosda Karya.

Nur, E. (2019). Strategi Komunikasi Tim Sukses Pada Kampanye Politik Untuk Memenangkan Calon Legislatif Kota Makassar. Jurnal Diakom, 2(1), 120-128.

Pito, T. A. (2006). Teori-Teori Politik. Nuansa Bandung.

Prihatmoko, J. (2003). Pemilu 2004 dan Konsolidasi Demokrasi. LP2I Press.

Schroder, P. (2018). Strategi Politik “Edisi Revisi Untuk Pemilu 2009.” Friedrich-Nauman- 
Stiftung fuer die Freiheit.

Sugiyono. (2014). Metode Penelitian Kuantitatif Kualitatif dan R dan D. Alfabeta.

Susanto, E. H. (2017). Media Sosial Sebagai Pendukung Jaringan Komunikasi Politik. Jurnal Aspikom, 3(3), 379-398.

Tim Prima Pena. (2006). Kamus Ilmiah Populer. Gitamedia Press.

Internet

Http://Tujuan \& fungsi Pemilihan Umum.ac.id./108400170. pdf. Diakses tanggal 15 Oktober 2019 jam 12:39 wib. 